\title{
Analisis Hubungan antara Gratitude Dengan Sense of School Belonging Pada Mahasiswa Karesidenan Madiun

\author{
(Correlation Analysis between Gratitude And Sense of School
} Belonging On College Students In The Madiun Region)
}

\author{
"Robik Anwar Dani, Marcella Mariska Aryono, dan Andi Cahyadi \\ Universitas Katolik Widya Mandala Surabaya Kampus Kota Madiun, Madiun, Indonesia \\ *)robik.anwar.dani@ukwms.ac.id
}

\begin{abstract}
Abstrak
Mahasiswa terkadang berperilaku seperti kurang antusias dengan kegiatan kemahasiswaan yang diadakan oleh universitas, sering tidak menghadiri perkuliahan tanpa alasan, dan kadang berperilaku yang tidak sesuai dengan nilai-nilai organisasi. Hal ini dapat mengindikasikan bahwa terdapat masalah dengan rasa memiliki mahasiswa terhadap sekolah (sense of school belonging). Rasa syukur (gratitude) mahasiswa terhadap universitas dapat menjadi faktor yang mempengaruhi rasa memiliki mahasiswa terhadap universitas. Oleh karena itu, penelitian ini bertujuan untuk mengetahui hubungan gratitude dan sense of school belonging. Metode penelitian yang digunakan dalam penelitian ini adalah metode kuantitatif korelasional. Subjek penelitian ini adalah 254 mahasiswa yang sedang menempuh pendidikan di berbagai perguruan tinggi di wilayah Madiun. Pengumpulan data dilakukan dengan menggunakan Tes Rasa Syukur dan Apresiasi (GRAT) Bentuk Pendek dan Skala Kepekaan Psikologis Sekolah (PSSM). Hasil penelitian ini dianalisis menggunakan analisis regresi linear sederhana. Analisis data menunjukkan bahwa besar koefisien regresi standar $\beta=0,323$ dengan signifikansi $\mathrm{p}<0,05$. Variabel gratitude terbukti berhubungan dan dapat memprediksi variabel sense of school belonging. Implikasi hasil penelitian ini dibahas lebih lanjut oleh peneliti.
\end{abstract}

Kata kunci: Sense of school belonging, gratitude, mahasiswa

\begin{abstract}
Students sometimes behave like they are not enthusiastic about student activities held by the university, absent in classes without reason, and their behavior do not fit the organizational values. These show that there is might a problem with the students' sense of school belonging. The students' gratitude regarding their university can be a factor that affects the students' sense of school belonging. Therefore, this study aims to determine the relationship between gratitude and sense of school belonging. The research method used in this research is quantitative method. The subjects of this research were 254 students who are studying in different university in the Madiun Region. The data was collected using the Gratitude Resentment and Appreciation Test (GRAT) Short Form and the Psychological Sense of School Membership Scale (PSSM). This study was analyzed using simple linear regression analysis. Data analysis showed that the standardized regression coefficient $\beta=0.323$ with a significance $p<0.05$. Gratitude is proven to be related and can predict the sense of school belonging. The implications of the results of this study are discussed further by the researcher.
\end{abstract}

Keywords: Sense of school belonging; gratitude; college students

\section{PENDAHULUAN}

Kebutuhan cinta dan rasa memiliki (love and belonging needs) tidak dapat dipisahkan dari kehidupan manusia. Perkembangan kebutuhan cinta dan rasa memiliki ini akan memunculkan rasa kepemilikan (sense of belonging) pada diri individu. Rasa 
kepemilikan ini muncul tidak hanya pada hubungan antar manusia saja, tetapi juga pada lembaga atau institusi pendidikan (Goodenow, 1993). Konsep rasa memiliki terhadap sebuah institusi pendidikan dikenal dengan istilah sense of school belonging. Goodenow (1993) menjelaskan bahwa sense of school belonging adalah kondisi yang terjadi ketika mahasiswa merasa diterima secara personal, diperhatikan, dilibatkan, dan didukung oleh orang lain di lingkungan sosial sekolah.

Manusia merupakan makhluk sosial yang tidak dapat hidup tanpa berinteraksi dengan orang lain. Dalam seluruh aktivitas yang dilakukannya, seseorang pasti berhubungan dengan orang lain. Dengan demikian, antara manusia yang satu dengan manusia lain tentu mempunyai sesuatu keterikatan. Hal ini sesuai dengan konsep hirarki kebutuhan Abraham Maslow tentang kebutuhan cinta serta kepemilikan (love and belonging needs). Kebutuhan ini telah ada semenjak kecil dan tumbuh bersamaan dengan perkembangan manusia (Robbins \& Judge, 2017). Perkembangan dari love and belonging needs ini membentuk rasa kepemilikan (sense of belonging) pada diri orang. Rasa kepemilikan ini timbul tidak hanya pada ikatan antar manusia saja, namun pula pada lembaga ataupun institusi pendidikan. Konsep rasa kepemilikan terhadap suatu institusi pendidikan disebut juga dengan istilah sense of school belonging. Sense of school belonging merupakan keadaan yang terjalin saat mahasiswa merasa diterima secara personal, diperhatikan, dilibatkan serta didukung oleh orang lain di area sosial sekolah (Goodenow, 2015). Sense of school belonging merupakan sesuatu perasaan yang menyenangkan, sebab terdapat perasaan diterima secara personal, diperhatikan, dilibatkan serta didukung oleh orang lain di lingkungan sosial universitas, sehingga dapat mempunyai keterikatan dengan universitas. Aspek-aspek yang menyusun sense of school belonging merupakan penerimaan teman sebaya, dukungan guru, serta general school belonging (Goodenow, 2015).

Berbagai riset dalam bidang pembelajaran juga menampilkan kesimpulan yang sama bahwa kebutuhan rasa memiliki (need for belonging) merupakan kebutuhan yang sangat penting untuk semua mahasiswa supaya bisa berfungsi secara baik dalam bermacam bidang di lingkup pembelajaran (Osterman, 2000; Wang \& Eccles, 2012, Lam, Chen, Zhang, \& Liang, 2015). Rasa kepemilikan (feeling of belonging) dapat memberikan pengaruh yang langsung yang kuat untuk motivasi mahasiswa, serta bisa menimbulkan keyakinan pada mahasiswa bahwa mereka tidak hanya mempunyai keahlian individual tetapi juga terdapat sumber-sumber sosial untuk menanggulangi hambatan ataupun kesusahan yang dialami (Goodenow, 2015). Walaupun demikian, tidak semua mahasiswa bisa mempunyai sense of school belonging yang baik.

Kenyataan di lapangan menunjukkan bahwa banyak mahasiswa yang menunjukkan sense of school belonging yang rendah, seperti kurang bangganya mahasiswa terhadap almamater tempat mereka menimba ilmu. Hal ini terjadi pada mahasiswa yang melanjutkan studi pada sebagian universitas di Madiun. Banyak mahasiswa yang mengatakan bahwa mereka kurang mempunyai kebanggaan terhadap almamater tempat mereka belajar. Salah satu faktor internal yang menjadi pemicu rendahnya sense of school belonging pada mahasiswa adalah terdapatnya anggapan negatif terhadap sekolah yang kemudian termanifestasi dalam perilaku. Contoh anggapan negatif tentang almamater adalah almamater tersebut bukan tempat yang terbaik dan memiliki mutu yang rendah. Saat individu memegang teguh keyakinan yang tidak realistis dan negatif mengenai dirinya atau pengalamannya, maka akan terjadi gangguan emosi dan akhirnya memengaruhi tindakan seseorang (Trower, Jones, \& Dryden, 2009). Beberapa perilaku yang dapat diamati adalah mahasiswa yang cenderung tidak bersemangat pada aktivitas kemahasiswaan yang diadakan oleh universitas, kerap tidak masuk tanpa alasan, serta melaksanakan perilaku yang sama sekali tidak menampilkan nilainilai suatu lembaga pembelajaran.

Banyak aspek yang mempengaruhi rasa kepemilikan terhadap sesuatu lembaga pembelajaran. 
Salah satu aspek internal yang mempengaruhinya adalah rasa syukur (gratitude) setiap mahasiswa dengan apa yang sudah mereka terima. Gratitude merupakan rasa berterima kasih serta senang sebagai reaksi penerimaan karunia, baik karunia tersebut ialah keuntungan yang diterima dari orang lain ataupun momen kedamaian yang ditimbulkan oleh keelokan alamiah (Seligman, Steen, Park, \& Peterson, 2005). Gratitude merupakan suatu pemahaman kognitif yang dapat mempengaruhi emosi seseorang. Gratitude merupakan merupakan emosi sosial yang berperan dalam meregulasi, memantapkan, serta mengeratkan relasi social (Watkins, 2014). Gratitude merupakan suatu wujud emosi positif yang terdiri dari rasa berkelimpahan, terdapatnya apresiasi terhadap adanya kenikmatan sederhana, serta terdapatnya apresiasi sosial. Adapun tiga komponen dasar gratitude yang bisa diukur merupakan rasa keberlimpahan yang kokoh (sense of abundance atau lack of a sense of deprivation), mengapresiasi kenyamanan sederhana (appreciation of simple pleasures), serta mengapresiasi orang lain (appreciation of others; Watkins, 2014). Gratitude yang dimiliki mahasiswa terhadap almamaternya, baik dari segi sarana dan prasarana ataupun peringkat universitas, dapat menjadi faktor pemicu rendahnya rasa kepemilikan mahasiswa pada almamater. Penelitian sebelumnya menunjukkan bahwa gratitude berhubungan positif dengan skor sense of school belonging (Diebel, Woodcock, Cooper, \& Brignell, 2016). Gratitude dapat meningkatkan pemahaman mengenai perilaku prososial dan perilaku positif terhadap guru dan teman, serta apresiasi positif terhadap staf sekolah.

Berdasarkan pembahasan teoritis dan fenomena aktual mengenai sense of school belonging serta gratitude tersebut, dapat diketahui bahwa sense of school belonging merupakan sesuatu yang penting karena dapat berperan positif dalam berbagai bidang di konteks pendidikan maupun sosial mahasiswa. Maka dari itu, peneliti memutuskan untuk melakukan penelitian ini untuk mengetahui hubungan antara gratitude dengan sense of school belonging pada mahasiswa di wilayah Madiun.

\section{METODE}

Penelitian ini menggunakan desain penelitian kuantitatif, yang bertujuan untuk mengetahui hubungan antara satu variabel prediktor dengan satu variabel outcome. Variabel prediktor dalam penelitian ini ialah gratitude, sedangkan variabel outcome penelitian ini adalah sense of schoool belonging. Populasi dalam penelitian ini adalah para mahasiswa se-Karesidenan Madiun, Jawa Timur. Pemilihan sampel riset ini menggunakan random sampling technique. Pengumpulan data dilakukan dengan kuesioner yang diberikan kepada responden penelitian. Alat pengumpul data yang digunakan yaitu Gratitude Resentment and Appreciation Test (GRAT) Short Form yang disusun serta dikembangkan oleh Watkins (2014) serta Psychological Sense of School Membership Scale (PSSM) yang dikembangkan oleh Alkan (2016). Kedua skala ini akan diterjemahkan ke dalam bahasa Indonesia memakai prosedur back to back translation, serta validasi isi dilakukan melalui proses expert judgement. Metode analisis yang digunakan dalam penelitian ini adalah analisis regresi sederhana untuk mengetahui hubungan antara dua variabel.

\section{HASIL}

Responden penelitian ini berjumlah 254 orang mahasiswa dengan persentase 20,47\% responden berjenis kelamin laki-laki (52 orang) dan sebanyak 79,53\% responden berjenis kelamin perempuan (202 orang). Usia responden cukup bervariasi, mulai dari usia 18 tahun hingga usia 57 tahun (gambar 1). Sebagian besar responden penelitian ini (78 orang) berusia 20 tahun. Responden yang berusia 19 tahun dan 21 tahun masing-masing sebanyak 47 orang. Jika dilihat dari kategori usia responden penelitian, sebanyak 248 orang berada di kategori dewasa awal (18-25 tahun), sedangkan sebanyak 6 orang berada di kategori dewasa awal hingga akhir. 


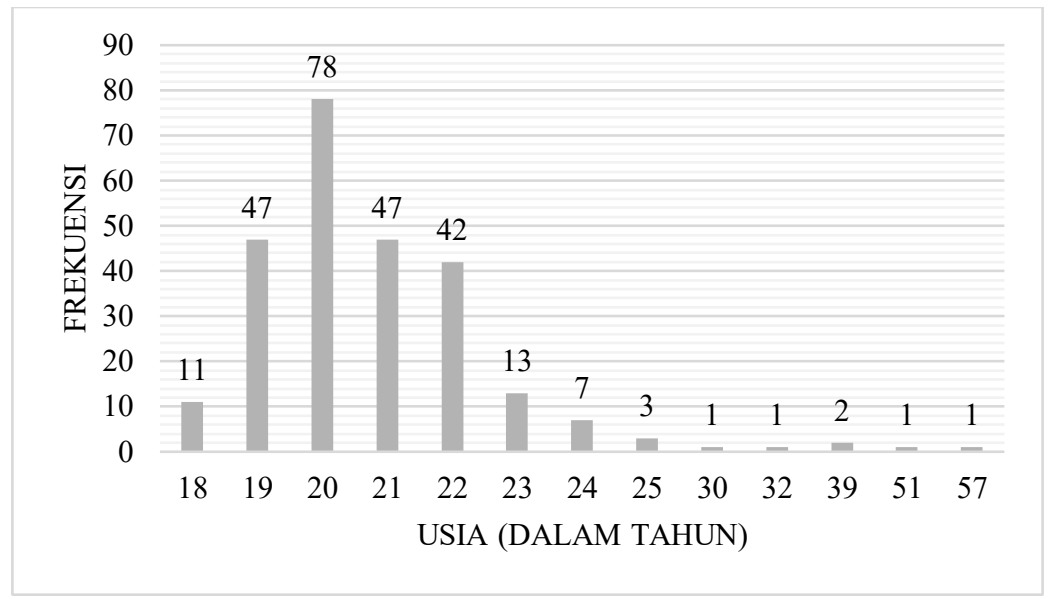

Gambar 1. Frekuensi Usia Subjek Penelitian

Tabel 1. Kategorisasi Gratitude dan Sense of school belonging

\begin{tabular}{ccc}
\hline \multirow{2}{*}{ Kategori } & \multicolumn{2}{c}{ Rentang Nilai } \\
\cline { 2 - 3 } & Gratitude & Sense of School Belonging \\
\hline Rendah & $0<56$ & $0<47$ \\
Sedang & $56 \leq x<64$ & $47 \leq x<53$ \\
Tinggi & $\mathrm{x} \geq 64$ & $\mathrm{x} \geq 53$ \\
\hline
\end{tabular}

Berdasarkan hasil analisis statistik, dapat diketahui bahwa skor rata-rata gratitude sebesar $\mathrm{M}=60,17(\mathrm{SD}=3,85)$ dan skor rata-rata sense of school belonging sebesar $\mathrm{M}=50,13(\mathrm{SD}=3,01)$. Skor gratitude dan sense of school belonging yang diperoleh dari 254 subjek dikategorisasikan ke dalam tiga kategori yaitu, tinggi, sedang, dan rendah. Kategorisasi pada kedua variabel ini dilakukan berdasarkan statistik empiris, yaitu menggunakan nilai rata-rata dan deviasi standar yang didapatkan dari data empiris yang dipakai sebagai referensi (Sugiyono, 2016). Tabel 1 menunjukkan rentang nilai pada tiap kategori dengan menggunakan kategorisasi berdasarkan data empiris.

Berdasarkan hasil kategorisasi gratitude dapat dilihat bahwa sebanyak 7,48\% (19 orang) responden memiliki gratitude pada tingkat yang rendah, sebanyak $72,44 \%$ (184 orang) responden memiliki gratitude pada tingkat yang sedang, dan sebanyak 20,08\% (51 orang) responden memiliki gratitude pada tingkat yang tinggi. Berdasarkan hasil kategorisasi sense of school belonging, dapat diketahui bahwa terdapat 9,06\% (23 orang) responden yang memiliki sense of school belonging pada tingkat yang rendah, sebanyak 70,47\% (179 orang) responden yang memiliki sense of school belonging pada tingkat yang, dan 20,47\% (52 orang) responden yang memiliki sense of school belonging pada tingkat yang tinggi. Dapat disimpulkan bahwa rata-rata subjek penelitian memiliki tingkat gratitude dan sense of school belonging yang sedang.

Dalam mengetahui hubungan antara gratitude dengan sense of school belonging pada mahasiswa di Karesidenan Madiun, digunakan teknik analisis data korelasi Product Moment. Hasil analisis korelasional menunjukkan koefisien korelasi sebesar $r=0,323$ dengan signifikansi $\mathrm{p}<0,05$. Hal ini berarti bahwa gratitude memiliki korelasi positif yang signifikan dengan sense of school belonging pada mahasiswa di Karesidenan Madiun, dimana semakin tinggi tingkat gratitude yang dimiliki oleh mahasiswa, maka akan semakin tinggi pula tingkat sense of school belonging yang dimilikinya. Sebaliknya, semakin rendah tingkat gratitude yang dimiliki oleh mahasiswa, maka akan semakin rendah pula tingkat sense of school belonging yang dimilikinya. 
Peneliti juga melakukan analisis regresi linear sederhana untuk menguji apakah variabel gratitude dapat memprediksi variabel sense of school belonging. Dengan sense of school belonging sebagai variabel outcome, hasil analisis data menunjukkan bahwa besar koefisien regresi standar $\beta=0,323$ dengan signifikansi $p<0,05$. Hal ini berarti bahwa gratitude terbukti berhubungan dan dapat memprediksi sense of school belonging yang dimiliki seseorang. Pada tabel 2, hasil analisis data menunjukkan pada kolom B pada constant (a) adalah 34,915. Sedangkan nilai gratitude (b) adalah 0,253 . Dengan demikian persamaan regresinya adalah $Y=34,915+0,253 X$. Dari persamaan tersebut dapat diketahui bahwa:

1. Konstanta sebesar 34,915 menyatakan bahwa jika tidak ada nilai gratitude maka nilai sense of school belonging menjadi sebesar 34,915.

2. Koefisien regresi $X$ sebesar 0,253 menyatakan bahwa setiap penambahan 1 nilai gratitude, maka nilai sense of school belonging bertambah sebesar 0,253.

Tabel 2. Hasil Analisis Regresi Linear Sederhana dengan Sense ofSschool Belonging sebagai Prediktor

\begin{tabular}{ccccc}
\hline \multirow{2}{*}{ Efek } & $\begin{array}{c}\text { Koefisien Non-Standar } \\
(\mathbf{B})\end{array}$ & SE & Koefisien Standar $(\boldsymbol{\beta})$ & $\mathbf{p}$ \\
\hline Constant & 34,915 & 2,815 & - & 0,000 \\
Gratitude & 0,253 & 0,047 & 0,323 & 0,000 \\
\hline
\end{tabular}

\section{DISKUSI}

Tujuan pada penelitian ini adalah untuk mengetahui hubungan antara gratitude dengan rasa sense of school belonging oleh mahasiswa yang kuliah di Karesidenan Madiun. Dalam hasil analisis uji hubungan dengan menggunakan korelasi product moment, dinyatakan bahwa terdapat korelasi yang positif antara gratitude dengan sense of school belonging pada mahasiswa di Karesidenan Madiun. Hal tersebut ditunjukkan melalui skor koefisien korelasi sebesar $r=0,323$ dengan signifikansi $\mathrm{p}<0,05$. Hasil analisis regresi juga menunjukkan hasil yang baik, dimana terbukti bahwa gratitude berhubungan dan dapat memprediksi sense of school belonging yang dimiliki seseorang.

Gratitude memberikan dampak yang positif terhadap berbagai aspek kehidupan. Salah satunya adalah sense of school belonging. Gratitude yang dimiliki oleh seseorang dapat meningkatkan pemahaman mengenai perilaku prososial terhadap pengajar dan warga universitas, serta loyalitas terhadap suatu almamater (Diebel, Woodcock, Cooper, \& Brignell, 2016). Gratitude membuat mahasiswa akan memiliki emosi positif terhadap diri serta lingkungannya, dan hal tersebut memberikan pengaruh yang positif terhadap lembaga pendidikan tempat mahasiswa tersebut belajar. Dengan memiliki gratitude, maka mahasiswa akan mengapresiasi apa yang telah dimilikinya dan juga memiliki apresiasi sosial (social appreciation). Apresiasi sosial ini ditunjukkan dengan rasa bangga terhadap lembaga tempat ia belajar. Dimana hal tersebut merupakan salah satu perwujudan dari general feeling to school (Demanet \& van Houtte, 2012).

Hasil penelitian ini sejalan dengan penelitian yang dilakukan oleh Diebel, dkk. (2016) yang menyatakan bahwa terdapat peningkatan sense of school belonging setelah partisipan menyelesaikan intervensi dengan menulis buku harian syukur. Dari penelitian tersebut dapat diketahui bahwa ketika seseorang mendapatkan intervensi menulis buku harian syukur dan skor syukurnya mengalami peningkatan, hal itu berpengaruh secara positif signifikan terhadap sense of school belonging. Gratitude yang dimiliki oleh seseorang akan mendorongnya untuk selalu bahagia dengan apa yang telah ia miliki dan memberikan apresiasi sosial terhadap lingkungan (Seligman, dkk., 2005).

Senada dengan paparan di atas, penelitian yang dilakukan oleh Hayati dan Andayani (2016) terkait dengan pelatihan gratitude untuk meningkatkan sense of school belonging pada siswa SMP menunjukkan bahwa terdapat peningkatan yang 
signifikan pada kelompok eksperimen setelah mendapatkan pelatihan gratitude. Penelitian tersebut membuktikan bahwa saat individu memiliki tingkat gratitude yang rendah, maka rasa sense of school belonging juga akan rendah. Begitu pula sebaliknya, jika individu memiliki gratitude yang tinggi, maka ia juga memiliki sense of school belonging yang tinggi pula.

Berdasarkan dua penelitian di atas, maka dapat diambil kesimpulan bahwa sense of school belonging akan meningkat setelah mereka diberikan pelatihan tentang gratitude. Gratitude dapat didefinisikan sebagai sebagai rasa berterima kasih dan bahagia yang ditunjukkan sebagai respon penerimaan karunia, baik karena suatu keuntungan yang diterima dari orang lain atau suatu momen kedamaian yang muncul karena keindahan yang alamiah (Seligman dkk., 2005). Berdasarkan hasil survei yang dilakukan oleh peneliti terhadap beberapa mahasiswa, salah satu hal positif yang diterima mahasiswa adalah mereka mendapatkan banyak kebaikan dari orang-orang yang berada di kampus mereka, dari teman-teman yang baik hingga dosen yang banyak membantu mereka selama di perkuliahan. Selain itu, mahasiswa juga banyak bersyukur karena mereka punya kesempatan kuliah, sebab tidak semua orang memiliki kesempatan untuk melanjutkan kuliah. Emosi positif yang dimunculkan oleh mahasiswa terhadap simple prelasure inilah yang membuat mereka memiliki sense of school belonging, meskipun lembaga pendidikan tersebut berada di kota yang relatif kecil. Selain appreciation of simple preasure, rasa kepemilikan terhadap sekolah juga dipengaruhi oleh aspek syukur lain yakni social appreciation yang ditunjukkan dengan mereka merasa bahagia ketika mendapatkan kebaikan dari orang-orang yang berada di lingkungan pembelajarannya.

Hasil penelitian ini juga menunjukkan bahwa rata-rata mahasiswa merasa bangga kuliah di kampus mereka dikarenakan kampus mereka mengajarkan nilai-nilai yang positif terhadap mereka. Dari 20 responden, hanya 1 orang yang tidak terlibat dalam kegiatan kampus, sedangkan 19 orang rata-rata mengikuti kegiatan yang ada di kampus, baik sebagai pengurus organisasi maupun hanya terlibat dalam kepanitiaan tertentu. Salah satu ciri seseorang memiliki sense of school belonging adalah kepercayaan pada nilai-nilai sekolah serta keterikatan dengan kegiatan akademik serta ekstrakurikuler sekolah (Dukynaite \& Dudaite, 2017).

Sejalan dengan penelitian terdahulu dan juga survei yang dilakukan oleh peneliti, hasil penelitian ini menunjukkan bahwa terdapat 65,35\% (166 orang) dari 254 mahasiswa yang memiliki gratitude dalam kategori sedang cenderung memiliki sense of school belonging yang sedang pula. Sebanyak 19,29\% (49 orang) mahasiswa yang memiliki gratitude dalam kategori tinggi juga cukup memiliki sense of school belonging. Meskipun masih terdapat $6,3 \%$ (16 orang) mahasiswa yang memiliki gratitude yang rendah, namun masih tetap cukup memiliki rasa sense of school belonging. Hal tersebut dapat disebabkan karena tidak hanya gratitude saja yang berpengaruh pada rasa kepemilikan terhadap sekolah, namun terdapat beberapa faktor lain yang juga dapat menyebabkan seseorang memiliki rasa kepemilikan terhadap sekolah. Terdapat faktor gender, kegiatan ekstrakurikuler, budaya sekolah, visi dan misi sekolah, peer support, teacher support, family involvement, dan lingkungan fisik yang dapat mempengaruhi seseorang memiliki rasa kepemilikan terhadap sekolah (Allen \& Kern, 2017). Hal ini membuktikan gratitude tidak hanya menjadi faktor utama penentu dari sense of school belonging pada mahasiswa. Akan tetapi faktor eksternal lain juga perlu diperhatikan dan dikontrol.

Penelitian ini berimplikasi pada timbulnya motivasi pada mahasiswa untuk lebih meningkatkan rasa kepemilikan dan kebanggaannya terhadap almamater tempat mereka menimba ilmu. Selain itu, penelitian ini juga berimplikasi pada sikap dan kebijakan universitas untuk senantiasa menciptakan iklim akademik yang nyaman, membangun, dan berdedikasi tinggi untuk kepuasan mahasiswa. Perbedaan penelitian ini dengan penelitian terdahulu adalah bahwa penelitian terdahulu lebih melakukan 
eksperimen menggunakan pelatihan gratitude pada mahasiswa untuk dilihat pengaruhnya pada sense of school belonging. Sedangkan, penelitian ini lebih membahas tentang hubungan antara gratitude dengan sense of school belonging. Keterbatasan dalam penelitian ini adalah terkait dengan proses pengambilan data yang dilakukan pada masa pandemi, sehingga perolehan responden menjadi kurang optimal. Selain itu, pengambilan sampel dalam penelitian ini yang menggunakan teknik random sampling membuat hasil penelitian tidak terkategorikan sesuai dengan demografi yang kemungkinan menjadi salah satu faktor yang berpengaruh terhadap sense of school belonging pada mahasiswa di Karesidenan Madiun.

Penelitian selanjutnya dapat lebih memasukkan variabel lain yang berpengaruh pada sense of school belonging. Dengan memperhatikan variabel lain, maka akan bisa dilihat sejauh mana pengaruh variabel lain terhadap sense of school belonging. Selain itu, dengan memperhatikan variabel lain peneliti bisa melihat dinamika antara rasa sense of school belonging dengan variabel selain gratitude. Saran lain dalam penelitan ini adalah terkait dengan pemilihan sampel penelitian. Penelitian selanjutnya dapat menggunakan teknik pemilihan sampel selain random sampling, seperti menggunakan cluster random sampling, sehingga factor-faktor penting seperti demografi dapat terwakili dengan baik.

\section{SIMPULAN}

Berdasarkan hasil penelitian dan pembahasan di atas, dapat disimpulkan bahwa terdapat hubungan yang signifikan dan bersifat positif antara gratitude dengan sense of school belonging pada mahasiswa di Karesidenan Madiun. Selain itu, gratitude juga terbukti dapat memprediksi sense of school belonging yang dimiliki seseorang. Dengan demikian gratitude yang dimiliki oleh mahasiswa dapat mempengaruhi tinggi rendahnya sense of school belonging akan almamater dimana mereka menimba ilmu.

\section{DAFTAR PUSTAKA}

Alkan, N. (2016). Psychological Sense of University Membership: An Adaptation Study of the PSSM Scale for Turkish University Students. The Journal of Psychology, 150(4), 431-449.

Allen, K. A., \& Kern, M. L. (2017). School Belonging in Adolescents: Theory, Research, and Practice. Australia: Spinger.

Diebel, T., Woodcock, C., Cooper, C., \& Brignell, C. (2016). Establishing the effectiveness of a gratitude diary intervention on children's sense of school belonging. Educational and Child Psychology, 33(2), 117-129.

Dukynaite, R \& Dudaite, J. (2017). Influence of School Factor's on Students' Sens of School Belonging. The New Educational Review, 39-52

Goodenow, C. (1993). The psychological sense of school membership among adolescents: Scale development and educational correlates. Psychology in the schools, 30, 70-90.

Goodenow, C. (2015). The psychological sense of school membership among adolescents. Psychology in the Schools 30, 70-90.

Hayati, I. N., \& Andayani, B. (2016). Pelatihan Kebersyukuran untuk Meningkatkan Sense of School Belonging Siswa SMP. Gadjah Mada Journal of Professional Psychology, 2(3), 130-141.

Lam, U. F., Chen, W. W., Zhang, J., \& Liang, T. (2015). It feels good to learn where i belong: School belonging, academic emotions, and academic achievement in adolescents. School Psychology International, 36(4), 393409.

Osterman, K. F. (2000). Students need for belonging in the school community. Review of Educational Research, 70(3), 323-367.

Robbins, S. P., \& Judge, T. A. (2017). Organizational behavior (7th ed.). Italy: Pearson.

Seligman, M. E. P., Steen, T. A., Park, N., \& Peterson, C. (2005). Positive psychology progress: empirical validation of interventions. The American Psychologist, 60(5), 410-421. 
Sugiyono. (2016). Metode Penelitian Kuantitatif, Kualitatif dan $R \& D$. Bandung: PT Alfabet.

Trower, P., Jones, J., Dryden, W. (2009). Cognitive Behavioural Counselling in Action. SAGE Publications Ltd.

Wang M., \& Eccles, J. S. (2012). Social support matters: Longitudinal effects of social support on three dimensions of school engagement from middle to high school. Child Development, 83, 877-895.

Watkins, P. C. (2014). Gratitude and the Good Life Toward a Psychology of Appreciation. Amsterdam: Springer.

Naskah masuk : 2 Desember 2020

Naskah diterima : 21 Juni 2021 